$\therefore \vdots$

(C)

DEC 261918 


\section{Board of Directors}

CHAS. H. O'ROURKE.

President

Ex-Chief Feed and Fertilizer Inspector of Louisiana
A. VIZARD, JR.,
Vice-President

Independent Naval Stores Company, Lake Charles, La.

JAS. M. MYATT,

Secretary-Treasurer Asst. Credit Man, Finlay, Dicks \& Co.

E. M. WILLIAMS, Merchant and Capitalist Vinton, La.

ROY P. STANDEFER, Hillsboro, Texas 


\section{P R E F A C E}

It was not until after the discovery of America that American Indian Corn became known. For more than fifteen centuries the world plodded along without this wonderful grain.

Civilization following the custom of the American Indian fed American Indian corn to livestock.

But today Corn is too valuable as human food to be used for livestock feed. 


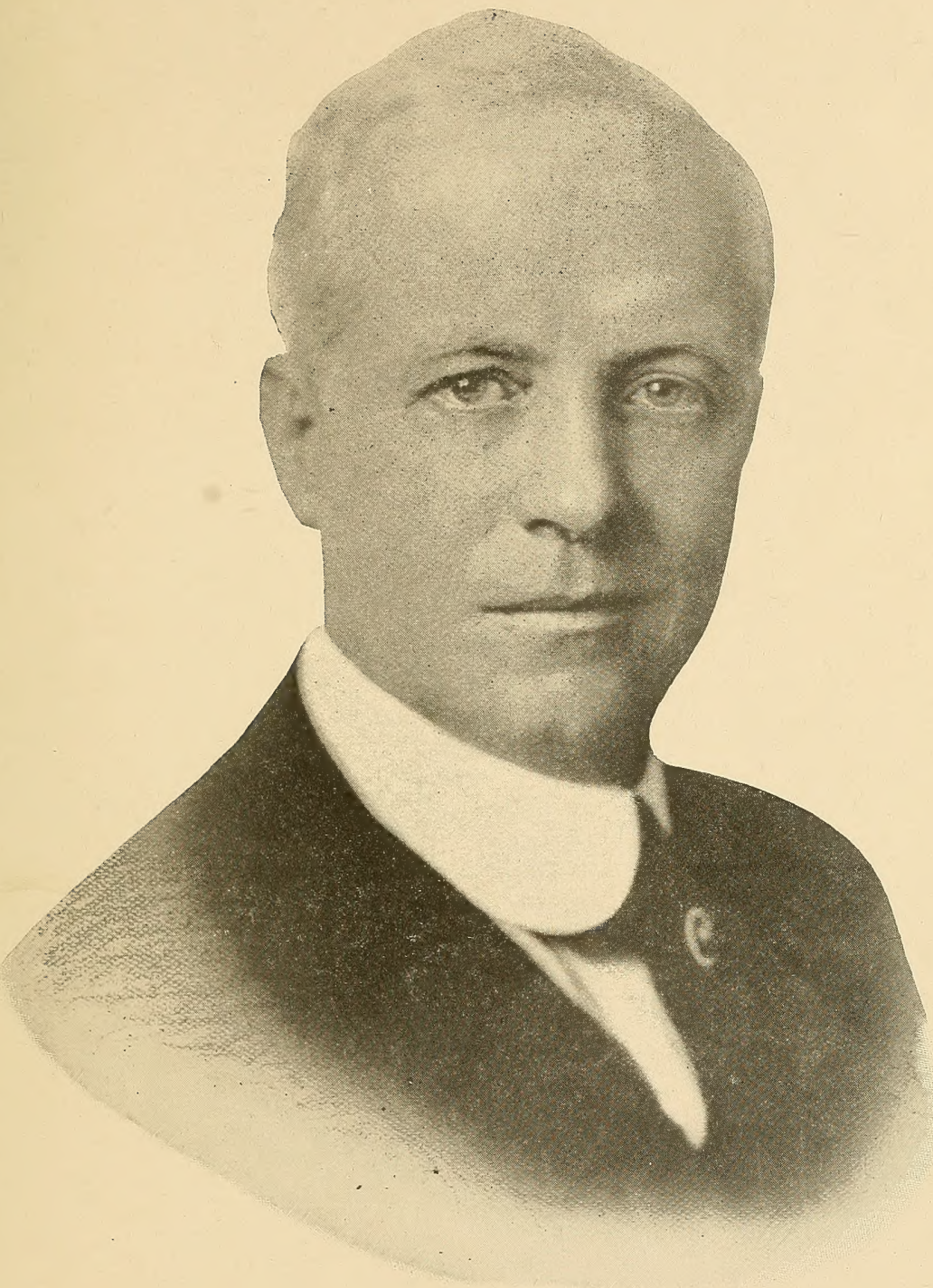

CHARLES H. O'ROURKE

President American Molassu Meal Co., Incorporated and

Inventor of Molasso Meal and Ekoro Feed Processes 


\section{N T RODU C TOR Y :}

A Shortage of Supply in any Necessity

increases the Value of any Waste By-product that might

be successfully used as a substitute.

The field defined in the following article is almost unlimited. In the State of Louisiana, alone, a practical tonnage exceeding 500,000 tons can be saved annually from the waste by-product of Sugar Cane. 
For seventeen years the inventor of the process herein referred to has been identified with the subject matter discussed and has labored conscientiously in an effort to solve the problem of economic and efficient feeding.

Aside from a successful termination of the World War, the most serious problem confronting the World today is the Food and Feed Problem. Before the beginning of the War its seriousness had already made itself felt. By-products are necessary to meet the situation in the Feed world, as the population has grown faster than food production. In this country the population is increasing to a greater extent than the opening up of tillable lands. The population is consuming the grains; livestock must be fed on nutritious by-products.

For eight years the president of this company was chief inspector of the Louisiana State Department of Agriculture and having fourteen Inspectors under his jurisdiction was called upon to pass on the inspection of thousands of shipments of Feeding Materials of all kinds and character. Astounded at the enormous amount of Feeding Material imported into Louisiana for live stock, he then began a study to solve the Feeding Problem in its relation to Louisiana. At that time Black Strap Molasses, the final waste product of the manufacture of Cane Sugar, was being dumped into the Bayous and Lagoons of Louisiana, polluting the waters, killing fish and eventually endangering animal life, until an edict of the War Department prohibited the practice.

Careful analyses were made of Black Strap Molasses, and experiments were conducted along the line of feeding it to livestock. In the practice of these researches he obtained employment in the Mixed Feed business and traveled in every State in the South, as well as in New York and Pennsylvania, for several years, selling Molasses Feeds to determine in a large and extensive experience, covering a wide area, the practical effects of feeding livestock with Molasses Feed. It was found that the same conditions existing in Louisiana were to be found in other States: The Virginias and Carolinas, Georgia, Florida, Alabama, Mississippi and Texas import enormous quantities of feedstuffs. Feeds are not only sold and imported to Louisiana, but to all States east of the Mississippi River, and the very heaviest importations of feed are found in the rich Dairy Sections of the East, where NOLASSO MEAL and EKORO FEED will find their greatest market.

Firm in the faith that Black Strap Molasses afforded the most economic Feeding Value on the American Market, a study was begun to find a reliable and suitable container 
(or absorbent) by which this valuable liquid could be economically reduced to a meal form. (The value of Molasses as a Feed is evidenced by the fact that Commercial Feeds mixed with Molasses are the biggest sellers on the American Market today.) In view of the simplicity of the solution of this problem it seems ludicrous now to look back upon the many blind trails traversed in the effort to solve the problem. But the one big handicap that blocked the progress was the established order of affairs. We are so prone to accept the "established rule" as a means of attainment that in the practice of this principle many experiments were made unsuccessfully with Feeding Materials enjoying a commercial value. Dried Sugar Beet Pulp was the material that eventually suggested the method upon which the final solution was founded.

These very conditions constitute the "established rule" in the Mixed Feed business today, and, while founded on sound economic principles, do not satisfactorily relieve the situation they aim to correct. One feature of the Mixed Feed business that places upon the feeder a heavy burden is the double haul on Crude Material. Thousands of tons of Cottonseed Meal are transported over the same road twice and this of itself adds to the cost. The Mixed Feed business is established on the principle of taking certain By-products of Straight Grains, mixing these with whole grains, and very often with Black Strap Molasses, and producing a Balanced Ration. The Protein base is often from Cotton Seed Meal. Many of these Mills are merely mixing plants that buy their Crude Materials in the Autumn and Fall, and, by the usual advance in price which invariably occurs after the Christmas Holidays, make a very respectable margin of profit. But the principle while practical is not economical in the fullest sense of the term; for while Mixed Feeds sell to the Feeder at less than Straight Grains would cost him (else the Feeder would buy Straight Grains), they are at all times at the mercy of the price of Straight Grains. A short Grain Crop af fords but little relief to the Feeder, because with a shortage in Grain production the price of Grain Byproducts are relatively high. This is the very thing that is wrong in the Mixed Feed business; so much so that the average person identified with the Mixed Feed industry calls it a "game" and not a business.

Therefore, in the solution of this problem, this one fact was never lost sight of: To produce a substitute for American Indian Corn for the feeding of livestock, the price of which would never be influenced in any manner whatsoever by the crop production of American Indian Corn. And in solving this problem Sugar Cane Bagasse was found to be the most wonderful and practical absorbent for this purpose.

Others in this country have not thought of Bagasse as a feed because the large feed industries are far removed 
from Louisiana and Bagasse would not ordinarily appeal to the casual observer as worth anything, because (and here again we are following the "established rule") the casual observer naturally supposes that if Bagasse was more valuable for any other purpose the Sugar Planter would not burn it as fuel, while the sugar planter is too busy making Sugar to stop during the grinding season (which, of course, is the only time that Bagasse can be obtained-and one reason why these researches covered so long a period) and experiment with Bagasse at a time when every thought and purpose is to transport the Cane to the Mill, make and market the Sugar. The reader must also understand that the growing of Sugar Cane and the manufacture of Sugar requires more attention and expense than any other agricultural crop produced and its harvest and grinding season involve between 90 and 100 days. (Just imagine the movement of four million tons and this tonnage has to be moved in from 90 to 100 days! If this tonnage was loaded in gondola cars 40 feet long, 20 tons to the car, it would make a continuous line of gondola cars extending from New Orleans to and beyond Hartford, Connecticut.) It is by no means a reflection on the Sugar Planter that he has not developed a more practical use for Bagasse, any more than it was on the Cotton Planter when he used to burn up his Cotton Seed to get rid of it, and the great industry built up with the By-products of Cotton Seed find a most wonderful prototype in the By-product from Sugar Cane. In fact it is positive proof that Nature has created in the South two of the World's most wonderful feeding materials: Protein and Fat as derived from Cotton Seed Meal; and Carbohydrates with its most desirable cubic bulk to be obtained from Sugar Cane Bagasse. (And the most remarkable feature of this fact is that Cotton Seed Meal is a high concentrate in feed value, while the Molasses Meal to be derived from Bagasse can be produced with an absolute certainty regarding its Cubic Bulk, and is beyond question the very product created by Nature for the mixing with Cotton Seed Meal; because, combined in proper proportion, they will make a Balanced Ration in proper bulk ratio to the feeding nutrients-which should be varied according to the physiological requirements of the animal to be fed. This accomplishment has long been sought by scientific feeders throughout the world-but the work of perfecting this process (covering more than a year in actual mechanical tests) has proven that Sugar Cane Bagasse is the only vegetable material known to this Company, the Cubic Bulk of which can be varied (in size) and its carbobohydrate content be made absolutely the same. High concentrate-feed is essential for the substantial fattening of hogs-but the theory of feeding corn, for instance, to horses and mules because hogs thrive on corn, is erroneous. The dimensions of an animal's stomach in proportion to the animal's physical size has a great deal to do with the character of feed to be fed each animal-age and weight are other factors. 
Cotton Seed Meal possesses ideal characteristics to coordinate with Molasso Meal and will effect the most perfectly Balanced Ration in the world. Because Cottonseed Meal is a high Protein concentrate, the protein contents of which is fixed in the process of oil making-dependent upon two factors: (i. e., the character and condition of the Cottonseed and the efficiency of the Oil Mill) it has long needed such a product as Molasso Meal to thoroughly establish its universal use as feed.

SUGAR CANE BAGASSE is the residue of Sugar Cane after the juice has been extracted. Bagasse has never been successfully exploited for any other purpose in Louisiana than fuel. It is true that a Mill was built some years ago at Amesville, La., to manufacture Fibreboard and produced a small quantity of this material but was abandoned for lack of funds. Another effort to make paper was made without practical success at Bayou Goula, Louisiana. Eastern interests are now promoting the recovery of commercial value in bagasse and have erected a plant at New Iberia, Louisiana, mainly to recover the fibre of bagasse for paper-making. This, however, is a chemical process and does not aim to produce feed for cattle in any of its phases. The Molasso Meal Process is a Mechanical Process. Some years ago in St. Bernard Parish, Louisiana, a Syndicate backed by British Capital, attempted unsuccessfully to exploit bagasse for Paper Making. Their failure can be traced directly to their lack of knowledge in successfully treating bagasse. Two facts substantiate this statement: The Wisconsin Experiment Station is reported now making between two and four tons of paper per day from Sugar Cane Bagasse in the Island of Cuba, and the Paper Mill built by the British Syndicate in St. Bernard Parish is now being successfully operated, making Paper from Yellow Pine Fibre.

Having familiarized themselves with the properties of Bagasse through years of study in an effort to solve the Feeding Problem, the promoters of this Company appreciate now why failure has been made in the many attempts to exploit Fibre of Sugar Cane for manufacture. The main reason for failure in properly treating bagasse is because of a lack of knowledge as to the main essential for its commercial recovery (economic drying). All previous attempts have been along the line of recovering Fibre Value only and ignoring the other two-thirds bulk of Bagasse, that is, Cellulose or Pith, and these efforts have been along chemical lines rather than mechanical. When the Bagasse leaves the last roller at the Sugar Mill it contains not less than $50 \%$ Moisture. Until this moisture is eliminated any effort to chemically treat the material must of necessity be so powerful (to effectively destroy foreign elements not necessary in fibre manufacture) that the tissues of the Fibre have been destroyed. Perhaps the same mistake would have been made along the Feed line had Fibre been as valuable as a Feed material as it was for pressboard or other Fibre fabrication. But the 
requirements necessary to the use of the cellulose of Bagasse for Feed demanded the separation of the Moisture. And thus in the solution of this mechanical problem has been evolved an economical, practical process for producing a Fibre from Sugar Cane Bagasse at least $70 \%$ pure.

The genius of man has not conceived an economic means either by chemical or mechanical process to extract all the Sugar from Sugar Cane. The average ton of Sugar Cane Bagasse produced in Louisiana contains from 3\% to $6 \%$ of actual Sugar. The average is nearer 6 than 3\%. This $6 \%$ exists in a material containing 50\% Moisture. When the Moisture is eliminated, instead of 6 pounds of actual Sugar existing in 100 pounds of wet Bagasse, 6 pounds are contained in 50 pounds of dried Bagasse. (Once put into palatable form the gastric juices of any healthy animal's stomach will absorb and assimilate this Sugar.)

This dried Bagasse contains $42 \%$ Fibre, $48 \%$ Cellulose (or pithy part) and 10\% Moisture. After years of effort and research to perfect the process, a practical means of economic drying was found. More than a year was devoted to a careful experiment to separate the Cellulose from the Fibre; because every unit of Fibre reduced in the Cellulose would increase the Sugar content of the Cellulose that much. Bagasse Cellulose is the most wonderful vegetable absorbent in the world. (This explains why the many attempts mentioned to exploit its Fibre were failures.

They were dealing with an unknown factor, ignorant of its treatment, regardless of its wonderful absorptive qualities, and failed.) It is Nature's own package as a container for Black Strap Molasses, and, properly mixed, produces a Carbohydrate Feeding Meal of wonderful value. Its commercial feasibility has already been successfully exploited by the British interests in England, who have developed a trade of more than twenty thousand $(20,000)$ tons annually; made in the Island of Java and transported half way round the world to reach its market (the British Isles) and yet not a pound made today in the United States.

The demand today for Feeding Material is unprecedented in the history of the world. The human race is growing faster than the production of grains. Hogs, Chicago market, cost more today than ever before. The greatest economic problem before the American people today-aside from winning the War-is a correct solution of the feeding problem. The average man does not grasp the full significance of this fact because-the average man, especially in the city, is so busy following his own line of vocation that he looks upon the feed problem as relating entirely to horses and mules. The smallest phase of this business will be supplying feed for draft animals. The greatest business will relate to the production of Meat, Milk and Butter-fats. The birth rate of the United States is in excess of deaths and the population is growing at the rate of 1,500,000 per year. While the human race 
is suffering an enormous reduction in the terrible conflict abroad, this elimination rather reduces the power of agricultural production hereafter, far greater than the reduction in human consumption thereby caused. The maimed and crippled will add to the nonproductive element of the world to a vastly greater extent than exists now, and agriculture must suffer enormously at a time when not a man can be spared. For the pathway has been from the farm and not to it. An early termination of the World War could not transform this serious situation. Both Feed and Fibre will offer their own problems in the future. The present situation in these commodities can only reflect a serious future regarding supply. Any industry having for its purpose the production of either of these commodities along practical lines, and particularly an industry producing both, cannot fail to thrive and prosper.

Our President visited England after the present war started and obtained Patent Rights on certain principles involved in this process, and, returning, organized a Company to exploit the proposition. After over a year's earnest work in completing a fully equipped Mill, through the criminal carelessness of others outside its own premises, the Mill was destroyed by fire on January 8th, 1917. Suit was entered in the United States District Court against the parties responsible and after a period of over a year, fighting technical legal delays the trial was held and after four days a compromise verdict was reached. Owing to unsettled conditions in the railroad world and necessity for awaiting the issuing of final patents to protect the investors in this Company and also arranging for the additional machinery needed, the marketing of stock has been held in abeyance until: now. The Molasso Meal to be made by this Company will comprise the Cellulose or Pith of Sugar Cane and Black Strap Molasses. The Process is fully covered by United States Letters Patent. Its feasibility as a practical Carbohydrate (or energy-producing Feeding Meal) is established beyond question by the volume of business already developed in the British Isles. It is not a Balanced Ration, as Protein and Fat are required to complete its efficiency in this respect. This product bears the same relation to the Sugar Cane Industry as Dried Sugar Beet Pulp bears to the Sugar Beet industry, the only difference being that the Sugar Beet industry has already taken advantage of their splendid byproduct. and developed a business in this country amounting to thousands of tons annually, while the Sugar Cane Industry has done nothing whatsoever to develope the value of Sugar Cane Bagasse, except to burn it as fuel like the sawmill gets rid of its slabs and sawdust.

The cost of this Meal predicated on present plans will positively insure one of the greatest reliefs known in the Feed World, and, even should normal prices come again, will always afford a wonderful betterment in the cost of feeding livestock. 
This is by no means an ordinary propaganda. Years of experience are behind the facts herein quoted. It is not an experimental proposition and the products of the industry are in universal demand and will continue. The process deals with a waste by-product that the World is ignorant of, and particularly in the enlightened United States; for the by-product is from the Sugar Cane industry that has had to struggle for its existence with unlimited handicap from every angle of its activity, restricting a free and progressive expansion of the industry.

Every unit of expense, every detail of equipment, every item of financial requirement has been most carefully compiled for the erection and operation of this new plant. Blue prints have been completed and bids received from every industry in position to furnish equipment. A long-term lease has been entered into which gives this Company valuable grounds with every facility of transportation at Port Chalmette, Louisiana, and the first plant will be completed on this site. Switch tracks are laid, our boiler room equipped with high-class Babcock and Wilcox boilers, a complete filteration plant and all other facilities are intact and completely installed, and engines and other equipment are under contract for early completion. Our plant will be convenient to the Industrial Canal and ideally located for the handling of tonnage. It will require an investment of $\$ 100,000.00$ to complete the initial plans now under way and the first plant will eventually take care of all business east of the Mississippi River. Our second and largest plant will be erected in the Sugar Belt of Louisiana convenient to the supply of Crude Material, and will involve an additional expenditure of $\$ 250,000.00$. As already stated, Molasso Meal is fully protected by letters United States Patent and this Company has exclusive right protecting its manufacture. The results already achieved insure the safety of the stockholders' investment-in a pioneer industry affording splendid profits to its stockholders.

The Company is in possession of samples of Molasso Meal more than six years old and which are in a perfect state of preservation. The process herein explained sterilizes the fermentable properties of Black Strap Molasses and prevents deterioration.

The technical merits of this proposition have already been amply exemplified and attested to through the work of such men as:

E. W. Kerr, M. E. (until recently Professor of Mechanical Engineering, Louisiana State University, and one of the highest authorities in the world on the Fuel efficiency of Sugar Cane Bagasse).

Dr. A. L. Metz (Dean of Chemistry, Tulane University), and analytical reports have been obtained from Dr. W. R. Dodson, Official Chemist of the Louisiana State Department of Agriculture.

This company appeals to your Public Spirit. The Feed Problem is vital to a Meat-eating race like the Anglo-Saxon. 
Every man, woman and child in this country is affected by it. The high cost of living is founded primarily upon the cost of Meat production and the expense involved in making Butter and Animal Fats. (Because when the cost of Bread is high the cost of producing these is likewise, since in the past the By-products of grains and cereals have been used for this purpose-and very often Straight Grains.) Every unit of Food conserved for human consumption will redound greatly to the benefit of humanity for a number of years to come, and this movement involves a tremendous step forward in the right direction.

Every 0 il Mill in the South could be made a Mixed Feed plant and the saving alone in the cost of transportation would greatly benefit them. Mr. Asa G. Candler has proven with his soft drink (Coca-Cola) what can be done with a standard formula marketed under a universally advertised Brand. This proposition to the Feed World is what Coca-Cola has proven to the Soft-Drink World. One is a luxury while the other is a necessity. Prohibition has helped the exploitation of Coca-Cola as a soft drink, and feeding the human family with a Grain production hardly sufficient for this purpose, coupled with a shortage of ships for exporting Cotton Seed Meal and Cake, is bound to help this Feed proposition.

The organization comprises men of experience in the feed business whose technical training qualify them for their special work. The experimental stage has been passed and every mechanical phase has been thoroughly tried and proven.

This is by no means a small undertaking. The problems involved have been at times almost impossible-because the work of perfecting the process has been along the Pioneer's Line, with very little known that could be relied upon without a most exhaustive research and experiment.

The above amount of capital required would positively earn:

6 Per Cent per annum for the Investment.

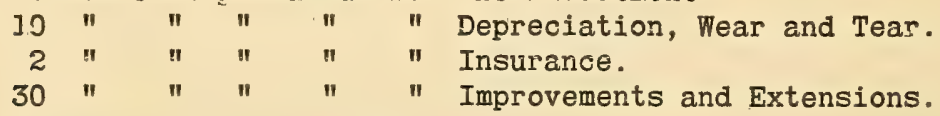

$\overline{\overline{48}}$ Per Cent minimum earning power on the investment, all of which can be presented in a comprehensive and complete form readily verified by competent authorities (Chemists and Engineers of your own choosing) or selected by a committee the Board of Directors may elect to choose.

You are cordially invited to become interested in this Company and you are earnestly solicited to assist in the organization of this splendid work.

We are enclosing for your consideration an application blank for stock and will reserve as many shares as you may desire-subject to our acceptance.

Yours very truly,

AMERICAN MOLASSO MEAL COMPANY, InC. 


\section{FEEDING BAGASSE}

A Paper by Chas. H. O'Rourke read before the Louisiana Sugar Planters Association, Sugar Experiment Station, Audubon Park, New Orleans, Louisiana, June 14 th, 1917.

Mr. Chairman and Members of the

Louisiana Sugar Planters Association:

A request to respond at this meeting to Prof. A. Guell's paper on "Burning Bagasse" is a privilege extended to me and highly appreciated. My limitations in Mechanical Engineering would have prompted me to decline, but as Prof. Guell has taken up the most important work of directing the Department of Mechanical Engineering at Louisiana State University, succeeding Prof. E. W. Kerr, whom I consider the highest authority in the world on the calorific Fuel Efficiency of Sugar Cane Bagasse, and is himself so deeply interested, with you gentlemen, in this most important subject; I have accepted the invitation with the hope that in a modest way my discussion will add some information to the subject from a different angle.

The fundamental principles of Fuel Efficiency is the utilization of every available heat unit with a minimum of loss (which cannot be entirely prevented) in the flue gases. According to the fuel used, the design of the boiler, furnace, variations of waste gases is perceptible. This waste gas proposition depends entirely upon the construction of the furnace, and of course the size of the stack. Any material containing a variable moisture content must prove a very difficult fuel to regulate accurately, furnace efficiency.

Mr. H. W. Raynor, who perfected and patented a Bagasse Dryer and devoted a number of years in an effort to solve the problem of drying Bagasse to increase its fuel efficiency, makes the claim that Sugar Cane Bagasse has the following Fuel Values:

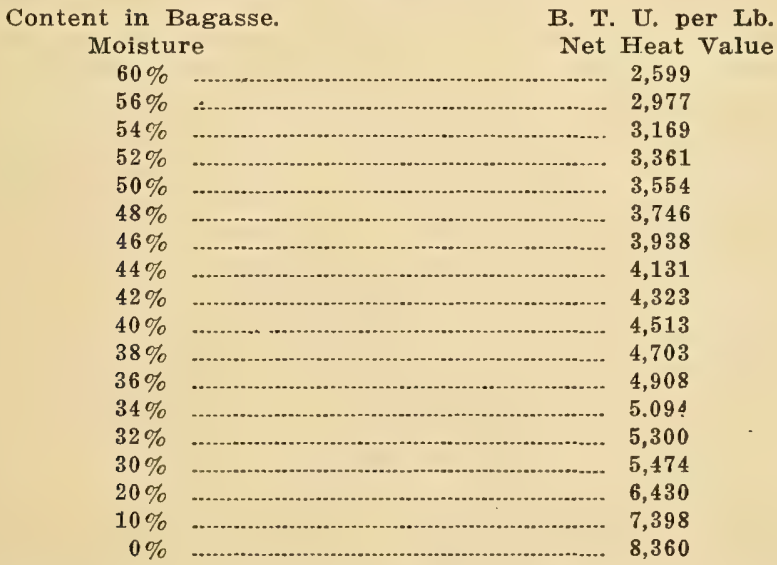

Taking one pound of Bagasse containing $50 \%$ Moisture (3,554 BTU) as a basis, by comparison with one pound of Fuel Oil (14,000 BTU) such a material is worth approximately one-quarter of the Fuel value of Fuel Oil. And yet were the Bagasse reduced to an absolutely aried state its increased fuel officiency would be (according to Prof. Kerr and concurred in by $\mathrm{Mr}$. Raynor) as $3,360 \mathrm{BTU}$ is to $3,554 \mathrm{BTU}$ or $59 \%$ (a little more than one-half the value of Fuel Oil at 14,000 BTU.)

Under the most scientific and economic principles it has been found that to evaporate 5 tons of water per hour from wet Bagasse containing $50 \%$ moisture, requires 400 pounds of coal (at $\$ 5.00$ per ton) in 
addition to the exhaust steam from a 300 H. P. engine, would represent $\$ 1.00$ fuel cost and under the most favorable conditions would only increase the fuel value of the material as 5,554 is to $8,360 \mathrm{BTU}$ (or 5,206 BTUs), which by comparison with coal at $\$ 5.00$ per ton would mean \$2.95. These figures do not include the fuel cost of the exhaust steam from the engine or the cost of labor. Starting with a Fuel Value in Bagasse of 3,554 BTU at an expense of $\$ 1.00$ for fuel in the operation, a recovered value of but $70 \mathrm{c}$ per ton has been obtained (since we start with a fixed fuel value in Bagasse containing $50 \%$ moisture; $\$ 1.25$ per ton as per above statement), and this difference in recovered value would more than be absorbed by the overhead expense.

In other words, it will cost practically as much to recover the fuel value of Bagasse by artificial drying as its increase in efficiency as fuel would represent.

But it seems to me the most practical way of arriving at the actual fuel value of Sugar Cane Bagasse is to eliminate it entirely from the calculation and to determine the amount of fuel necessary to run a Sugar Mill without the use of any Bagasse.

Prof. Kerr lays down the principle that "not less than 11/2 BHP should be provided per ton of cane crushed per 24 hours. Therefore a Sugar Mill crushing 1,000 tons of Sugar Cane per 24 hours requires $1,000 \times 1 \frac{1}{2}$ BHP or 1,500 BHP.

If Fuel Oil is used 173 gallons will evaporate 20,000 1bs. of water. (Standard Oil Company-authority). This basis is on a parity with the efficiency of Pratt No. 4 coal. It requires 441.15 gallons of Fuel Oil to evaporate $51,000 \mathrm{lbs}$. of water equal to $1,500 \mathrm{BHP}$ per hour.

Should coal be used as a substitute fuel at the Sugar Mill, 1,500 BHP per twenty-four hours would require 124,000 lbs. coal. (One pound of Pratt No. 4 will evaporate $10 \mathrm{lbs}$. of water.)

On the basis of Fuel Oil it would require $10,587.60$ gallons or 252.14 bbls per 24 hours; or operating 100 days 25,214 bbls. to run a properly equipped Sugar Mill grinding 1,000 tons per 24 hours. Should the most economical Sugar Mill in Louisiana be taken as a comparison there should be deducted from this total of $10,587.60$ gallons Fuel Oil per 24 hours, 3,000 gallons (the amount of Fuel Oil they are using in conjunction with Bagasse at present). This would bring the additional fuel required per 24 hours (if Bagasse was eliminated entirely) to $7,587.60$ gallons Fuel Oil or 180.65 bbls. For 100 working days of 24 hours each, 18,065 bbls. (758,730 gallons) Fuel Oil.

$18,065 \mathrm{Bbls}$. Fuel Oil at $\$ 1.00$ per bbl

$\$ 18,065.00$

On this basis 25,000 tons of Bagasse is equal in value to........72c per ton

Should coal be used as a substitute fuel at the Sugar Mill, 1,500 BHP per 24 hours would consume 124,000 1bs., or 62 tons at $\$ 5.00$ per ton: $\$ 310.00$ per 24 hours. For 100 full running (24-hour) days would be 6,200 tons at $\$ 5.00$ per ton: $\$ 31,000.00$. Now taking the fuel problem at one of the most economic Sugar Mills in Louisiana as a basis, onethird of their fuel expense is oil. On this ratio, one-third of $\$ 31,000.00$ is $\$ 10,333.33$, which represents the amount of fuel other than Bagasse that has to be supplied, leaving $\$ 20,666.67$, which represents the fuel value of Bagasse used in conjunction with coal at $\$ 5.00$ per ton.

For 25,000 tons of Bagasse from such a mill on this basis would be $.82 \mathrm{c}$ per ton.

The average Sugar Mill in Louisiana, as you well know, operates on both Fuel Oil and Bagasse, some using coal instead of Fuel Oil. But the great handicap to the use of Bagasse as fuel is the disadvan- 
tage in the generation of steam in the furnace arising from the moisture in Bagasse. Steam is efficient in extinguishing fire because steam will expand and expel the oxigen, which, aside from heat is the most important factor in combustion. When the furnace is fed with wet Bagasse the moisture in Bagasse will generate steam in the furnace in such great volume that it minimizes the supply of oxigen the instant the steam is generated until it is heated to such an extent that it becomes a gas itself. The result is that at the time of feeding the wet Bagasse into the furnace the wet Bagasse will absorb the biggest part of the heat from the fire and very little is transmitted to generate steam into the boiler until all the moisture in the Bagasse is evaporated and the full supply of oxigen enters the furnace after the generated steam from the wet Bagasse has escaped through the stack.

Just pause for a moment and contemplate the amount of water fed into the average boiler-furnace per hour at our Sugar Mills during grinding season and the laws of energy wasted out of the stack! A Sugar Mill grinding 1,000 tons of cane per 24 hours, feeds into the furnace 125 tons or 30,120 gallons of water per 24 hours. This energy in steam is equal to a loss of $300 \mathrm{BHP}$ per hour. In other words, gentlemen, the 1,000-ton Sugar Mill loses 350 BHP per hour to enjoy a fuel efficiency of 1,500 BHP per hour and to overcome the unknown factor burns Fuel Oil, wood or coal in addition to Bagasse.

Increased efficiency has been developed by certain Sugar Mills through the installation of forced draft, but while the increase in combustion in the chamber-by the supply of increased oxigen-has occurred, it has also increased the loss through flue gases. It is a fact, however, that when forced draft is properly used there is a marked increase in the surplus Bagasse and a decrease in Fuel Oil required.

A number of attempts have been made and progress accomplished to increase the fuel efficiency of Bagasse through the utilization of waste flue gases for drying purposes. Improvements in furmace-construction, Dutch Ovens, Hoppers, Shaker Grates and other devices, including forced draft; all of which have helped to some extent.

A factor that will prove of much greater benefit to the Louisiana Sugar Planter will be tho oil development in the Sugar Belt that I predict will prove greater in the next few years than ever before, for I believe this whole State is over a subterranean Lake of Petroleum. The biggest Gas Well in the World has already been brought in, in Terrebonne Parish-a fact that will afford the Sugar Planters in that section a wonderfully cheap and efficient fuel.

Nature never intended Bagasse to be used as fuel. It is possible to violate Nature's Iaws from sheer necessity, but sooner or later conditions will demand a correction. And the correction in this instance is the utilization of Bagasse as feed and its ultimate substitution with some other fuel. For a number of years I have labored persistently to solve the problem of economic feeding in its relation to Livestock in Louisiana. There are a number of you gentlemen who have shipped Bagasse to me and whom I have visited in regards to this subject. In the practice of these researches I have made a number of shipments of Bagasse to the East, where practical tests with mechanical devices have been made to determine the very best mechanical principles to follow in the treatment of this material, and I have gone to London, England, to make sure that the principle was not onIy correct but could not be encroached upon. I am satisfied beyond any doubt that we have in Louisiana the most abundant supply of suitable material for the manufacture of a Carbohydrate Feeding Meal as can be found anywhere in the World. Sugar Cane Bagasse is the most wonderful vegetable absorbent in the World, and properly handled as it leaves the last roller of the Sugar Mill can be converted into a Carbohydrate Feed Meal that will afford a practical solution to the Feeding Problem in the South. It is not a balanced ration, as protein and fat must be added to increase its efficiency in this respect. It is by no means a reflection on the Sugar Planter that you have not developed a more practical use for Bagasse, any more than it was for the Cotton Planter 
when he used to burn up his Cotton seed to get rid of it, and the great industry built up with the by-products of Cotton Seed find a most wonderful prototype in the by-product from Sugar Cane. In fact, it is positive proof that Nature has created in the South two of the World's most wonderful feeding materials: Protein and Fat as derived from Cotton Seed Meal and Carbohydrates with its most desirable cubic bulk to be obtained from Sugar Cane Bagasse. And the most remarkable feature of this fact is that Cotton Seed Meal is a high concentrate in feed value, while the "Molasso Meal" to be derived from Bagasse can be produced with an absolute certainty regarding its cubic bulk, and is beyond question the very product created by Nature for the mixing with Cotton Seed Meal; because, combined in proper proportion they will make a balanced ration in proper bulk ratio to the feeding nutrients-which vary according to the physiological requirements of the animal fed. This is a result long sought for by expert feeders.

Louisiana has paid out millions of dollars to the West for both food and feedstuffs. Western Sugar Beet refiners come down to our very doors and undersell Refined Beet Granulated at anywhere from 11 to 15 points under the Louisiana Market. How can he do it? How can he produce more sugar on less ground and make it cheaper than Louisiana? He can't. And yet he undersells Louisiana Sugar right here at home. There's a reason for everything under the sun. One reason why the Western Sugar Beet Refiner can do it is because he does not burn up the Sugar Beet after extracting what sugar he can from it. Because he has organized the producing factors and has lought for transportation rates. Because he pays for beets on a basia of what beets are worth to him. And making sugar in the West under conditions whereby he enjoys a wonderful business from the consuming population West of the Rocky Mountains and likewise a much lower freight rate to these consuming points, can absorb 10 to 15 points differential on the market east of the Rockies cr East of the Mississippi River-wherever our freight rates begin to equalize with his-and break even. But one great big factor among these reasons is the Feed Factor. The Western Sugar Beet refiner has taken advantage of Germany's practice and has utilized every unit of value in his business. The volume of business done in dried sugar beet pulp amounts to millions of dollars annually. In 1916 Louisiana produced $4,000,000$ tons of Sugar Cane, from which $3,000,000$ tons of juice were extracted, leaving $1,000,000$ tons of Bagasse as food for flame, when this material could be converted into livestock feed worth not less than $\$ 7,500,000.00$. Its efficiency as feed has already been developed elsewhere. It is not a theory but an established fact. Sugar Cane Bagasse is worth less than one dollar per ton as fuel and offers one of the hardest problems the Sugar Planter is confronted with. Because it hampers a fixed and certain steam pressure and often retards the cooking of juice at a time when the steam is insufficient to supply the mill's full requirements.

Gentlemen, I seek your co-operation and will afford those who do co-operate with me a profit from their Bagasse which they have never known before. I shall arrange with a number of Sugar Mills to take a quantity of their Bagasse this Fall, without any interruption to their important process of grinding, and hope to establish blants at a number of points in the Sugar Belt in the next few years.

The serious period of history upon which we are entering demands that every unit of value be availed of. America with its unsurpassed genius and incomporable democracy must sustain the high standard of efficiency in War that it has so nobly achieved in Peace. Both the Food and Feed supplies are as vital to a conquering Nation as Ships, Men and Munitions. Let us get together and conserve as large a part of this waste in Louisiana as is possible, at a time when America needs every unit of Feed and Food values possible to conserve.

Gentlemen, I thank you.

SPECIAL. NOTE-The BTUs in one pound of Fuel Oil has been figured at 14,000 (the recognized standard is not less than 18,000 BTU) in order to place its fuel efficiency on the same basis as coal. 


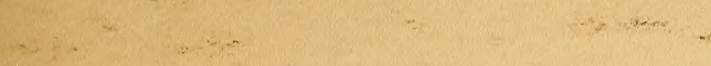


LIBRARY OF CONGRESS

|||||||||||||||||||||||||||||||||||||||||||||||

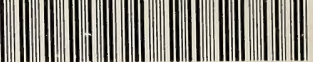

00028306039 